\title{
Heat Transfer in the Ducts of the Cooling Systems of Traction Motors
}

\author{
A.A. Aleksahin ${ }^{1}$, A.V Panchuk ${ }^{2 *}$ L.A. Parkhomenko ${ }^{2}$, H.V. Bilovol ${ }^{2}$ \\ ${ }^{I}$ V.N. Karazin Kharkov National University \\ ${ }^{2}$ Ukrainian State University of Railway Transport \\ *Corresponding author_E-mail: pan4uk_81@ukr.net
}

\begin{abstract}
Requirements for increasing thermal efficiency heat exchangers, which lead to energy saving, material and reduction cost, and as a result of reducing the impact on the environment, led to the development and use of various methods of increasing heat transfer. These methods are called intensification of heat transfer processes. Intensification of heat and mass transfer processes is of great import ance for making progress in improving the existing and creation of new energy and heat-exchange equipment. Among the ways of intensifying heat transfer, the swirling of flows of working media is one of the simplest and most common methods and is widely used in energy-intensive channels of nuclear power plants, heat exchangers, aeronautical and rocket and space equipment, chemical industry and other technical devices. We have proposed formulas to determine the cooling air velocity necessary to ensure the required temperature condition of the traction motor assemblies. Decrease in the power of fans in the cooling system using the artificial heat transfer intensification in the ducts was estimated based on the generalization of the results of calculations.
\end{abstract}

Keywords: cooling system, cooling air rate, fan power, traction motor, thermal convection, tape swirl generators.

\section{Introduction}

The reliability and economical operation of electric machines are inextricably linked with the problem of the efficiency of cooling their structural elements. The permissible load of any equipment is usually determined by heating of the most sensitive elements of electrical insulation. The permissible heating temperatures are regulated depending on the properties of the electrical insulation materials [1]. Thus, the maximum permissible temperature is $105^{\circ} \mathrm{C}$ for heat resistance class $\mathrm{A}$ insulation and $120^{\circ} \mathrm{C}$ for class $\mathrm{E}$ insulation. In accordance with the thermal operating conditions of electrical insulation, the temperature of the armature for most types of traction motors installed in locomotives should not exceed $120-140^{\circ} \mathrm{C}$, and that of the main and additional poles - 130$160^{\circ} \mathrm{C}$.

The armature cores are cooled with air which is blown through the ventilation ducts, which are formed during the assembly of the core of electric steel stamping sheets with vent openings. The cooling system is usually made in the form of ducts of circular or rectangular cross-section (the ratio of the section sides of the rectangular ducts is 0.3 to 0.5 ). The length of the ducts is 0.32 to 0.42 $\mathrm{m}$ for ED engines, and $0.3 \mathrm{~m}$ for GS engines. The rated air velocity in cooling system ducts is $14.75-28.9 \mathrm{~m} / \mathrm{s}$ for ED engines, and about $40 \mathrm{~m} / \mathrm{s}$ for GS engines. The power to the fan drive, necessary to ensure the required temperature level, is $8-10 \%$ of the power of the traction.

\section{Analysis of Recent Studies and Publications}

In general, heat transfer in cylindrical tubes and non-circular ducts is calculated using the same criteria equations, using the equiva- lent diameter of the cross section as the characteristic size for ducts of a complex shape. However, the flow of the substance in direct non-circular ducts is complicated by a number of features vs the flow in a circular tube, the main one of which is that the hydrodynamic characteristics of the flow change along the perimeter of non-circular ducts. Due to the overlapping of boundary layers, developed laminar regions and secondary flows are formed near the angles, directed along the bisectors to the duct angles. The noted features of the flow naturally cause the uneven distribution of the local values of heat transfer coefficients along the perimeter of the duct. Due to overlapping of the boundary layers near the angles, the heat transfer intensity in these areas is lower than in the middle of the sides [2]. In the central part of the perimeter of rectangular ducts, the heat transfer coefficient is approximately 10$15 \%$ higher, and in the angular part it is $25 \%$ lower than the mean cross-sectional values. Such a distribution of heat transfer coefficients along the perimeter can cause heating of the material of the structures which are adjacent to the angular areas.

Since part of the energy generated by the power plant of the locomotive is used for driving the fans of the cooling system of traction motors, the efficiency of heat removal affects significantly not only the thermal state of the engine structure, but also the efficiency factor of the power plant and fuel consumption.

One of the ways to improve the performance of the cooling system is providing conditions to increasing the heat transfer coefficients between the duct walls and the coolant. Intensified heat transfer in the ducts with a fixed thermal load causes either a decrease in the required flow rate of the heat carrier for the same heat transfer surface, or a decrease in the heat transfer surface area at a constant flow rate of the coolant. Devices for the heat transfer intensification are successfully used in various types of equipment. Thus, for example, the use of annular diaphragms and grooves enables the reduction of the weight and volume of the heat transferring part of 
gas and water refrigerators by a factor of 1.5 [3]. Reduction of the heat transfer surface of a circular tube using the trip wire for the range of $5 \cdot 103<\operatorname{Re}<20 \cdot 103$, according to $[4,5,6]$, is about $30 \%$. The use of tubes with serrated helical fins enables to reduce the dimensions of the heat exchanger by 1.5 to 1.75 times $[7,8]$. The use of tubes with grooved spiral fins of convective heating surfaces of boiler units allows considerable increase in the intensity of heat transfer vs. the tubes with continuous finning. According to the findings of [9], such increase will be 32 to $43 \%$ for the staggered tube banks and 17 to $32.8 \%$ for in-line tube banks.

The most common techniques of heat transfer intensification in the ducts are increase of heat outlet due to creation of higher levels of external flow turbulence and use of surfaces with artificial roughness. In the first case, the turbulence is increased due to perturbations directed from the floe core, in the second case, the intensification of heat transfer occurs due to perturbations in the wall layer. The expediency of applying of a specific method of intensity is decided upon for each specific case separately.

There are various measures to create wall turbulence, but their essence is providing conditions to remove the boundary layer from the wall. Moreover, according to multiple authors, turbulence with sharp outlines should be avoided [2]. In the powerful vortices arising before and behind them, energy dissipation is commensurate or even exceeds turbulence in them [10], which is associated with large hydraulic losses.

\section{Determination of the Purpose and Problem of the Study}

The implementation of surfaces with wall swirlers for cooling systems of electric motor rotors is difficult from the technological point of view. Using the flow twisting devices, such as spiral inserts, twisted tapes, tangential inlet of the cooling heat carrier, can be more suitable in this case.

When spiral wire or tape swirl generators are used, the increase in the heat transfer intensity due to local separation of the boundary layer is supplemented with the flow swirling effect $[11,12]$. In turn, the loss of pressure in such a system is determined by the friction of the swirled flow, separation of the vortices from the edge of the swirler and the energy consumption for vortex formation.

The use of twisted tapes seems to be the most promising options for the cooling systems of stators of traction motors, which are easy to manufacture and mount, require low material consumption, can be used both in designing new cooling systems and upgrading the existing equipment.

The basic geometric characteristic of spiral inserts, which determines the processes of heat transfer and pressure loss in the heat carrier flow, is the pitch of twist of the spiral (S), which is equal to the axial dimension when the tape is rotated $360^{\circ}$ (Figure 1).

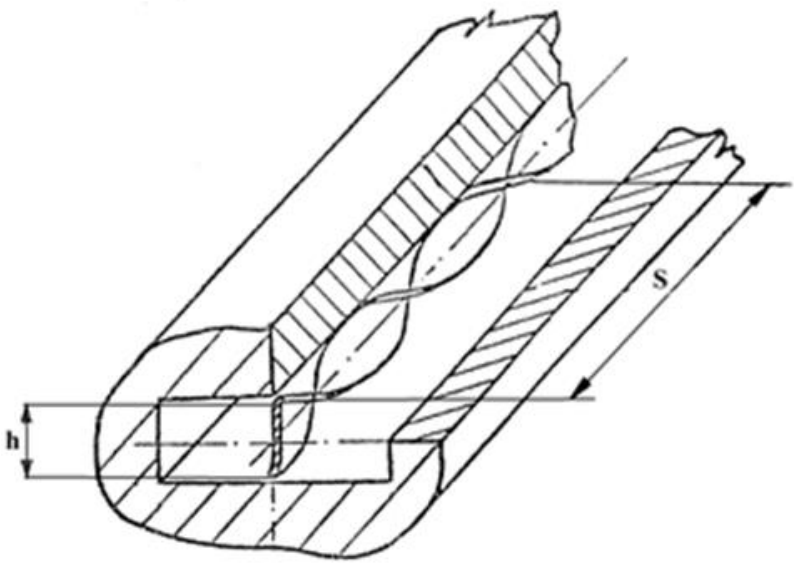

Fig. 1: Installation of the tape swirl generator in the rectangular duct

Equations for finding of heat transfer and pressure loss coefficients in the ducts with tape swirl generators are given below:
Criteria equations for calculation of heat transfer and pressure losses in the rectangular duct are [13]:

- heat transfer

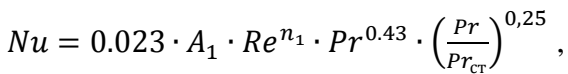

where

$A_{1}=\left(1+\frac{h}{s}\right)^{14.05} ; \quad n_{1}=1.727-0.927 \cdot\left(1+\frac{h}{s}\right)$

- hydraulic loss factor

$\xi=0,334 \cdot \frac{\mathrm{A}_{2}}{\operatorname{Re}^{\mathrm{n}_{2}}}$

where

$A_{2}=\left(1+\frac{h}{s}\right)^{9.4} ; n_{2}=0.5-0.25 \cdot\left(1+\frac{h}{s}\right)$

Criteria equations for calculation of heat transfer and pressure losses in the circular tube are [14]:

- hear transfer

$N u=0.023 \cdot \mathrm{A}_{1}^{/} \cdot \operatorname{Re}^{0,8} \cdot \operatorname{Pr}^{0.43} \cdot\left(\frac{P r}{P r_{\mathrm{cr}}}\right)^{0,25}$

where

$\mathrm{A}_{1}^{\prime}=1+\frac{5,65 \cdot 10^{4}}{R e^{1.2}} \cdot \frac{d}{S}$

- hydraulic loss factor [15]

$\xi=0,316 \cdot \frac{\mathrm{A}_{2}^{\prime}}{R e^{0.25}}$

where

$A_{2}^{\prime}=1+14.35 \cdot\left(\frac{d}{s}\right)^{4}$

The following indications are adopted in the above formulas:

$\mathrm{Nu}$ - Nusselt criterion; Re - Reynolds criterion; Pr - Prandtl number for cooling air at a mean temperature; $\operatorname{Pr}_{\text {ст }}-$ Prandtl number for cooling air at a temperature of the wall; $h$ - height of the rectangular duct; $\mathrm{d}$ - diameter of a cylindrical tube.

The diameter is accepted as a characteristic dimension to determine Nusselt and Reynolds criteria for the circular tube, and the equivalent diameter for the rectangular duct, which is calculated using the formula

$d_{\ni}=\frac{4 \cdot f}{p}$,

where $\mathrm{f}$ - cross-sectional area; $\mathrm{p}$ - perimeter.

The purpose of this article is to evaluate the effect of the geometric parameters of inserts in the form of a twisted tape on the power of the fans spent for pumping the air through the ducts of the cooling system of the rotor of traction motors.

The main part of the study. The power of the drive of cooling fans depends on the air flow $\mathrm{V}$, pressure losses during the air motion $\Delta \mathrm{P}$ and efficiency factor of the fan $\eta_{\mathrm{B}}$. In general, the design formula for power value is as follows:

$N=\frac{V \cdot \Delta P}{\eta_{\mathrm{B}}}$.

Pressure losses during the medium motion in the ducts can be determined using the formula [15] 
$\Delta P=\xi \cdot \frac{l}{d} \cdot \rho \cdot \frac{\omega^{2}}{2}$

where 1 - length; $d-$ duct diameter; $\rho$ - specific gravity of the medium; $\omega$ - velocity.

For instance, the formula (2) can be used to determine the pressure loss coefficient in the "smooth" rectangular duct. If $\mathrm{h} / \mathrm{s}=0$ is plugged in

$\xi_{0}=\frac{0.334}{R e_{0}^{0.25}}$

where $R e_{0}=\frac{\omega_{0} \cdot d_{3}}{v_{0}}-$ Reynolds criterion; $\mathrm{d}_{3}-$ equivalent duct diameter; $v_{0}$ - kinematic viscosity coefficient of the medium.

The rate of the cooling heat carrier in the duct $\omega_{0}$ can be determined using the continuity equation

$V_{0}=\omega_{0} \cdot f$

In view of the dependencies (7), (8), (9) the equation (6) for the "smooth" rectangular duct is written as

$N_{0}=\frac{0.334 \cdot \omega_{0}^{2.75} \cdot v_{0}^{0.25} \cdot l \cdot f \cdot \rho_{0}}{2 \cdot d_{3}^{1.25} \cdot \eta_{\mathrm{B}}}$

In view of the dependency (2), (7) the power spent for the drive of the cooling fans, if the tape swirl generators are used for intensification of heat transfer processes, is

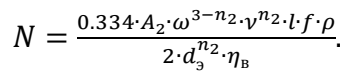

The change of power of cooling fans when inserts for artificial heat transfer intensification are used in the rectangular ducts is evaluated using the ratio

$\frac{N}{N_{0}}=A_{2} \cdot \frac{\omega^{3-n_{2}}}{\omega_{0}^{2.75}} \cdot \frac{\rho}{\rho_{0}} \cdot \frac{v^{n_{2}}}{v_{0}^{0.25}} \cdot d_{\ni}^{0.25-n_{2}}$.

Similarly, using the data $[16,17]$ on the hydraulic loss coefficients in the cylindrical tubes with helical inserts, an equation for determination of the change of power of the fans when tape swirl generators are used in the circular ducts can be obtained. The equation is as follows

$\frac{N}{N_{0}}=\left(\frac{\omega}{\omega_{0}}\right)^{2,75} \cdot\left(\frac{v}{v_{0}}\right)^{0,25} \cdot \frac{\rho}{\rho_{0}} \cdot A_{2}^{\prime}$

The velocity of the heat carrier in the duct can be determined based on the analysis of the heat removal conditions. The thermal balance of the duct of the cooling system without artificial heat transfer intensification is as follows

$Q_{0}=\alpha_{0} \cdot F \cdot\left(t_{\text {ст. } 0}-t_{\text {ср.0 }}\right)=G_{0} \cdot c \cdot\left(t_{\text {вых. } 0}-t_{\text {вх. } 0}\right)$,

where $\mathrm{Q}_{0}$ - heat consumption (necessary heat removal); $\alpha_{0}$ - heat emission coefficient; $\mathrm{F}$ - heat transfer surface area; $\mathrm{t}_{\text {ст. } 0}$ - temperature of the duct wall; $t_{c p .0}=0,5 \cdot\left(t_{\text {sx. } 0}+t_{\text {sbx. } .0}\right)$ - mean temperature of the heat carrier; $\mathrm{t}_{\mathrm{Bx} .0}, \mathrm{t}_{\mathrm{Bux} .0}-$ duct inlet and outlet temperature of the heat carrier, respectively; $\mathrm{G}_{0}-$ mass flow of the cooling heat carrier; c-specific heat capacity of the heat carrier.

Heat emission coefficient from the duct surface to the cooling heat carrier without artificial heat transfer intensifiers $\alpha_{0}$ can be determined, for instance, from the equation (1), if the value $h / s=0$ is plugged in. The velocity value of the cooling medium ensuring the required temperature of the walls in the "smooth" rectangular duct obtained from the balance ratio (14) is

$\omega_{0}=\left[\frac{0.023 \cdot\left(\theta_{0}-0.5\right) \cdot\left(\frac{F}{f}\right)}{P r_{0}^{0.57}}\right]^{5} \cdot\left(\frac{v}{d_{\ni}}\right)$, where $\Theta_{0}=\left(\mathrm{t}_{\text {ст.0 }}-\mathrm{t}_{\mathrm{вх.} .0}\right) /\left(\mathrm{t}_{\mathrm{вых.} .0}-\mathrm{t}_{\mathrm{вх.} .0}\right)-$ relative temperature of the wall of the "smooth" duct.

Since for the rectangular ducts, the ratio of the heat transfer areas to the cross-section is $F / f=4 \cdot l / d_{3}$, for the air cooling systems manufactured from the rectangular ducts, the equation (15) is as follows

$\omega_{0}=\left[0,112 \cdot\left(\theta_{0}-0.5\right) \cdot \frac{l}{d_{3}}\right]^{5} \cdot\left(\frac{v}{d_{3}}\right)$,

where 1 - duct length.

The change of the air velocity ensuring the required temperature of the walls in the "smooth" rectangular duct with a cross-section of $11 * 23 \mathrm{~mm}, 0.38 \mathrm{~m}$ long is shown in Figure 2,a.

The shown curve illustrates the cooling modes of the duct walls within the range $95 \leq t_{c m} \leq 105^{\circ} \mathrm{C}$ at the inlet air temperature in the cooling system $t_{b x .0}=20^{\circ} \mathrm{C}$. When the temperature values of the duct walls and the duct inlet cooling air temperature are constant, the in crease of the relative temperature $\Theta_{0}$ means the outlet air temperature reduction thus requiring the increase of velocity, and consequently, the cooling air consumption.

If the temperatures of the "smooth" duct and the duct with heat transfer intensification are equal $t_{c m}=t_{c m 0}$ and the inlet air temperature in the cooling system is equal, air velocity in the ducts

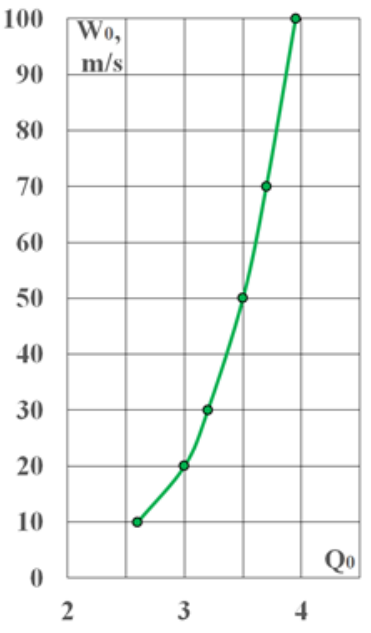

a

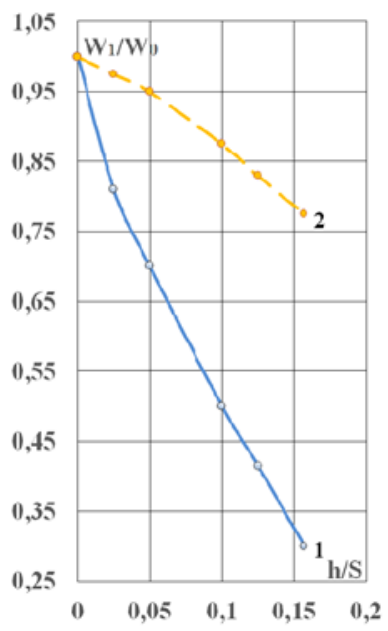

b
Fig. 2: Change of the ventilation air velocity in the ducts of the cooling system of the electric motor: $a$ - without flow swirling; $b$ - with the ducts with tape swirl generators. 1 - rectangular duct; 2 - cylindrical duct.

with swirl generators can be found using the equation (17), obtained from the balance ratios for the cooling system

$\frac{G \cdot c}{\alpha \cdot F}=\theta_{1}+\Phi_{0} \cdot \theta_{2}$,

where

$\theta_{1}=\frac{\left(t_{\text {вых. } 0}-t_{\text {вых }}\right)}{2} \cdot\left(t_{\text {вых }}-t_{\mathrm{BX}}\right) ; \quad \theta_{2}=\frac{\left(t_{\text {вых.0 }}-t_{\mathrm{BX}}\right)}{\left(t_{\mathrm{Bdx}}-t_{\mathrm{BX}}\right)} ;$

$\Phi_{0}=\frac{G_{0} \cdot c}{\alpha_{0} \cdot F} ; G_{0}=\omega_{0} \cdot \rho_{0} \cdot f ; G=\omega \cdot \rho \cdot f$ - mass air flow in the smooth duct and in the duct with a swirl generator, respectively.

After the transformations, the expression for the velocity of the heat carrier in the rectangular duct with a helical insert is written as

$\omega=\left[\left(\theta_{1}+\Phi_{0} \cdot \theta_{2}\right) \cdot 0,023 \cdot A_{1} \cdot\left(\frac{F}{f}\right) \cdot \operatorname{Pr}^{0.57}\right]^{k_{1}} \cdot\left(\frac{v}{d_{\ni}}\right)$

where $k_{1}=\frac{1}{1-n_{1}}$.

Since the Prandtl number for the air within the range of operating temperatures, which are characteristic for the thermal modes of the 
traction electric motors, is practically constant, the expression (18) for air cooling systems made of rectangular ducts can be transformed as

$\omega=\left[\left(\theta_{1}+\Phi_{0} \cdot \theta_{2}\right) \cdot 0,112 \cdot A_{1} \cdot\left(\frac{l}{d_{3}}\right)\right]^{k_{1}} \cdot\left(\frac{v}{d_{3}}\right)$,

When the manufacturing options of the cooling systems are compared, the flow velocity values of the heat carrier in the duct with a rounded tape $\omega_{1}$ are notable, where the same heat transfer coefficients are ensured as in the "smooth" duct. The value of this velocity for the rectangular ducts can be obtained from the equations (1), (16). After transformation, we obtain

$\omega_{1}=\left[\omega_{0}^{0,8} \cdot\left(\frac{v}{d_{9}}\right)^{n_{1}-0.8} \cdot\left(\frac{1}{A_{1}}\right)\right]^{\frac{1}{n_{1}}}$

Measuring $\omega_{1}$ velocity in the ducts depending on the parameters of the twisted tape is shown in Figure 2,b. The provided design data illustrate the mode which is characterized with the following conditions: temperature of the duct wall $\mathrm{t}_{\mathrm{cr}}=100^{\circ} \mathrm{C}$, inlet air temperature in the cooling system $\mathrm{t}_{\mathrm{BX}}=20^{\circ} \mathrm{C}$, outlet air temperature $\mathrm{t}_{\mathrm{Bbx}}=$ $50{ }^{\circ} \mathrm{C}$. According to Figure 2,b, flow whirling with a tape swirl generator causes the reduction of the air flow velocity necessary to cool the duct walls. With small twist pitches, the cooling air velocity should be about twice as low to ensure the same heat transfer coefficients as in the "smooth" duct. According to Figure 3, when twisted tapes are used to intensify the heat transfer process in the ducts, the power required for performance of the fans of the cooling system can be reduced by at least $12 \%$. The design parameters have been obtained on the basis of (13) taking into account (15) and (20).

Taking into account the specific flow in the non-circular ducts, a different degree of effect of tape swirl generators on the intensity of heat transfer and loss of pressure in such ducts and in cylindrical tubes should be expected. In the non-circular ducts, the inserts are expected to have a more material effect on the average heat transfer coefficients resulting from the action of perturbations caused by flow swirling on the angular areas.
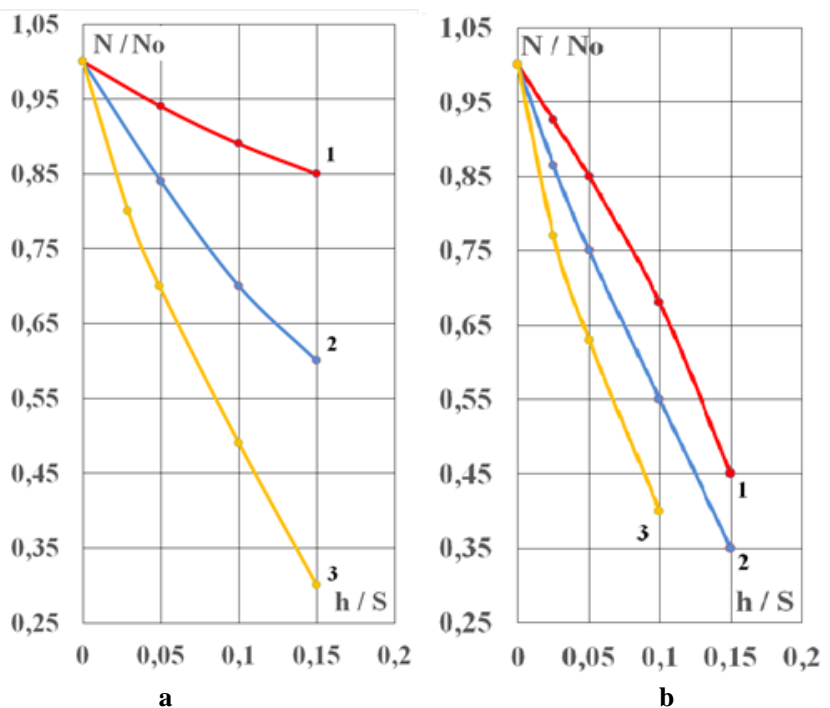

Fig. 3: Power loss of the fans of the cooling system of the traction motor with intensified heat transfer

$\mathrm{a}-\mathrm{t}_{\mathrm{cT}}=100^{\circ} \mathrm{C}, \mathrm{t}_{\mathrm{Bx}}=20^{\circ} \mathrm{C} ; \mathrm{b}-\mathrm{t}_{\mathrm{cT}}=100{ }^{\circ} \mathrm{C}, \mathrm{t}_{\mathrm{Bx}}=20^{\circ} \mathrm{C}$;

$1-\left(\mathrm{t}_{\text {вых }}-\mathrm{t}_{\text {вх }}\right)=27.5^{\circ} \mathrm{C} ; 2-\left(\mathrm{t}_{\text {вых }}-\mathrm{t}_{\text {вх }}\right)=30^{\circ} \mathrm{C} ; 3-\left(\mathrm{t}_{\text {вых }}-\mathrm{t}_{\text {вх }}\right)=35^{\circ} \mathrm{C}$.

Comparison of the intensity of heat transfer in a circular tube and in a rectangular duct with a 1:3 aspect ratio when the flow is swirled with a tape swirl generator is shown in Figure 4. The calculations have been performed using formulas (1) and (3). According to Figure 4, using tape swirl generators in the rectangular duct provide better effect of the increase of heat transfer coefficients (about by $7-13 \%$ ), than in a circular tube.
However, the pressure loss is also higher in the rectangular duct. For the considered flow parameters in the calculations, an excess of pressure losses of about $7-19 \%$ is recorded.

The change of the power spent for air pumping through the cylindrical ducts of the cooling system can be evaluated using the formula (13) taking into account the dependency (20). The results of the calculations are shown in Figure 5.

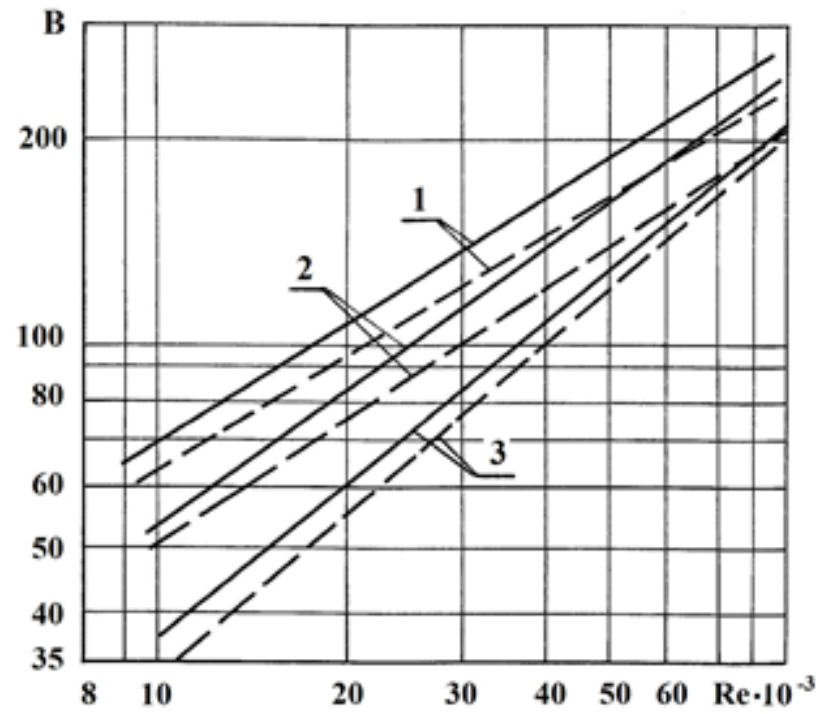

Fig. 4: Intensity of heat transfer in the rectangular duct and circular tube when the flow is twisted rectangular duct; _ _ _ _ circular tube [10];

$1-\mathrm{S} / \mathrm{h}=7.13 ; 2-\mathrm{S} / \mathrm{h}=14.66 ; 3-\mathrm{S} / \mathrm{h}=\infty$

$\mathrm{B}=\mathrm{Nu} /\left[\operatorname{Pr}^{0,43} \cdot\left(\operatorname{Pr} / \operatorname{Pr}_{\mathrm{cT}}\right)^{0,25}\right]$.

It also includes results of calculations for a rectangular duct. Comparison has been performed under the condition that the diameter of the cylindrical duct and the equivalent diameter of a rectangular duct are equal. The temperature regime for the compared cases is characterized by the values $\mathrm{t}_{\mathrm{cT}}=100{ }^{\circ} \mathrm{C}$ and $\mathrm{t}_{\mathrm{BX}}=$ $20{ }^{\circ} \mathrm{C}$.

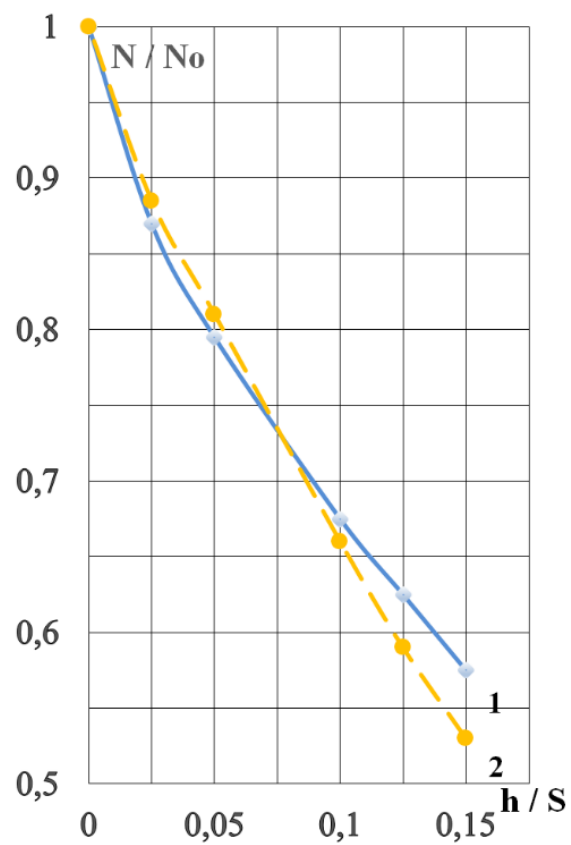

Fig. 5: Comparison of the power of the fan of the cooling system of the traction electric motor when the air flow is twisted in the duct 1 - rectangular duct, 2 - circular tube.

Figure 5 shows that despite the use of tape swirl generators in a rectangular duct allows a more significant cooling air velocity decline (and consequently, the air consumption) vs. a circular tube, 
advantages of a particular one of the considered shapes of the duct cooling system could not be identifies.

\section{Conclusions and Prospects of the Study, Further Development in This Field}

1. Installation of tape swirl generators in the ducts of the cooling system of traction electric motors results in an increase in the average heat transfer coefficients by a factor of 1.5-2. Calculation formulas are proposed for determining the velocity necessary to ensure the temperatures of the structural elements.

2. The intensified heat transfer rate ensures the possibility of reducing the cooling air consumption. Despite the increased pressure along the air flow path, the use of tape swirl generators allows to reduce the share of power of the energy generating plant spent for the drive of cooling fans.

3 . The level of reduction in the required power for fans of the cooling system depends on the twisting pitch of the tape swirl generator, the operating temperature of the engine and is at least $12 \%$.

4. Despite the varying degree of effect of tape swirl generators on the friction and heat transfer characteristics in the circular and rectangular ducts, no material effect of the shape of the path on the change in the power of the cooling fans has been recorded.

\section{References}

[1] Besprozvannykh A.V. Matematicheskiye modeli i metody elektroizolyatsionnykh konstruktsiy: uchebnoye posobiye, «Khar'kovskiy politekhnicheskiy institut», Natsional'nyy tekhnicheskiy universitet, 2012. - $108 \mathrm{~s}$.

[2] Pavlovskiy V.G. Osoblyvosti hidrodinamiki y teploobminu v nekruhlykh kanalakh: monohrafiya, «Khar'kovskiy politekhnicheskiy institut», Natsional'nyy tekhnicheskiy universitet, 2006. - 104 s.

[3] Dreytser G.A., E.K. Kalinin. "Issledovaniye intensifikatsii teploobmena $\mathrm{v}$ prodol'no omyvayemom vozdukhom tesno puchke trub”, Inzhenerno-fizicheskiy zhurnal, 1968, t.15, №3, - S. 408415 .

[4] Klachak A. "Heat transfer in the tubes with wire and tape turbulators", Proceedings of the American society of mechanical engineers, heat transfer, Vol.95, No. 4, (1973), pp. 557-559, https://doi:10.1115/1.3450114

[5] Smith Eiamsa ard and Pongjet Promvonge, "Enhancement of heat transfer in a tube with regularly spaced helical tape swirl generators", Solar Energy, Vol.78, No.4, (2005), pp. 483-494, https://doi.org/10.1016/j.solener.2004.09.021

[6] Smith Eiamsa ard and Pongjet Promvonge, "Heat transfer characteristics in a tube fitted with helical screw tape with/without core rod inserts", International communications in heat and mass transfer, Vol.34, No.2, (2007), pp. 176-185. https://doi.org/10.1016/j.icheatmasstransfer.2006.10.006

[7] Kuntysh V.B., Iokhvedov F.M. "Vybor effektivnoy poverkhnosti nagreva dlya sozdaniya kompaktnogo vozdukhonagrevatelya (kalorifera)", Izvestiye VUZov. Energetika, 1970, №5. - S. 68-72.

[8] Shabanian S R, Rahimi M, Shahhosseini M and Alsairafi A A, "CFD and experimental studies on heat transfer enhancement in an air cooler equipped with different tube inserts", International communications in heat and mass transfer, Vol.38, No.3, (2011), pp 383-390, https://doi.org/10.1016/j.icheatmasstransfer.2010.12.015

[9] Galushak I.V. Pidvyshchennya efektivnosti konvektyvnykh poverkhon' nahrivu kotel'nykh ahrehativ $\mathrm{v}$ systemakh teplohazopostachannya: avtoreferat dysertatsiyi kandydata tekhnichnykh nauk, Kharkiv, 2016. - $20 \mathrm{~s}$

[10] Kalinin E.K., Dreytser G.A., Yarkho S.A. "Intensifikatsiya teploobmena v kanalakh", Moskva, Mashinostroyeniye, 1972. - $220 \mathrm{~s}$.

[11] Migay V.K. "Intensifikatsiya teploobmena v trubakh so spiral'nymy zakruchivatelyamy, Teploenergetika, 1968, №11, - S. 31 33.

[12] N. Sahiti, F. Durst, A. Dewan. "Heat transfer enhancement by pin elements", International journal of heat and mass transfer, No.48, (2005), pp. 4738-4747. https://doi.org/10.1016/j.ijheatmasstransfer.2005.07.001
[13] Aleksahin A.A., Dreytser L.S., Bondarenko V.S., Torchinskaya I.T. "Povysheniye intensivnosti teploobmena V aksial'nykh ventilyatsionnykh kanalakh shikhtovannykh serdechnikov tyagovykh elektricheskikh mashin s pomoshch'yu lentochnykh zavikhriteley", Vestnik Khar'kovskogo Politekhnicheskogo Instituta, elektromashinostroyeniya i avtomatizatsiya promyshlennykh predpriyatiy, 1988, №255, Vypusk 13, - s 35-43.

[14] Teplotekhnicheskikh Spravochnik v 2 t. / Pod obshch. red. V. N. Yureneva i P. D. Lebedeva. - vtoraya izdaniye, pererabotannoye, Moskva, Energiya, 1976, T.2. - 896 s.

[15] Spravochnik po gidravlike / Pod obshch. red. V.A. Bol'shakova, Kiyev, Vysshaya shkola, 1984. - 343 s.

[16] Smithberg E., Landis F. "Friction and forced convection heattransfer characteristics in tubes with twisted tape swirl generators", Proceedings of the American society of mechanical engineers, Heat transfer, Vol.86, No.1, (1964), pp. 52-55.

[17] E.K. Akpinar, Y. Bicer. "Investigation of heat transfer and exergy loss in a concentric double pipe exchanger equipped with swirl generators", International Journal of Thermal Science, Vol.44, No.6, (2005), pp. 598-607. https://doi.org/10.1016/j.ijthermalsci.2004.11.001 